\title{
Simple Additive Weighting to Diagnose Rabbit Disease
}

\author{
Ramadiani $^{1 *}$, Dyna Marissa ${ }^{1}$, Muhammad Labib Jundillah ${ }^{1}$, Azainil $^{2}$ and Heliza Rahmania Hatta ${ }^{1}$ \\ ${ }^{1}$ Faculty of Computer Science and Information Technology Mulawarman University, Samarinda - Indonesia \\ ${ }^{2}$ Faculty of Teacher Training and Education Mulawarman University, Samarinda, Indonesia
}

\begin{abstract}
Rabbit is one of the many pets maintained by the general public in Indonesia. Like other pet, rabbits are also susceptible to various diseases. Society in general does not understand correctly the type of rabbit disease and the way of treatment. To help care for sick rabbits it is necessary a decision support system recommendation diagnosis of rabbit disease. The purpose of this research is to make the application of rabbit disease diagnosis system so that can help user in taking care of rabbit. This application diagnoses the disease by tracing the symptoms and calculating the recommendation of the disease using Simple Additive Weighting method. This research produces a web-based decision support system that is used to help rabbit breeders and the general public.
\end{abstract}

\section{Introduction}

Rabbits are funny and cute animals that can be nurtured and breed by everyone. Many people maintain rabbits because they have clean, smooth, soft feathers like carpets, in addition to low cost of feed and not a lot of noise. Other causes that make people interested in maintaining the rabbit because it is one source of lowcholesterol meat providers, which can be an alternative treatment for some people who have asthma and reproductive problems [1-2].

The type of rabbits varies depending on the origin of the country where the rabbit is alive. There are rabbits that have thick, long and smooth fur, but there are also thin, fluffy, soft rabbits such as carpets. There are rabbits that have long, wide and standing ears, but many rabbits are short, small and face down. There are rabbits whose body size reaches a weight of more than $5 \mathrm{~kg}$, but there is also a type of rabbit whose body size is small and weighs not more than $3 \mathrm{~kg}$. Each rabbit has its own uniqueness, such as feathers, eye color, ears, and body size. Some types of rabbits need special attention in their daily care [1].

Like other pets, rabbits are also susceptible to disease attacks. Unfortunately, not everyone understands correctly the various diseases of rabbits and his treatment [2]. If the rabbit is already affected by the disease, it is necessary to get special treatment. If we are slow in overcoming it, it will cause other rabbits infected by sick rabbits. In addition, the highest cause of rabbit death is disease. Therefore, prevention needs to be done early on by knowing the symptoms of rabbits affected by the disease. Good prevention is expected to reduce rabbit death rates.
The study aims to assist the determination of Rabbit disease type, by applying Simple Additive Weighting method. Based on the background that has been described then needed a system that can provide disease diagnosis in rabbits as a consideration for the care of the disease appropriately. This study uses SAW method because this method is one of multi-criteria settlement, where in diagnose rabbit disease there are many symptoms or criteria to be considered.

\section{Literature Review}

\subsection{Decision Support System}

Decision Support System (DSS) is a computer-based information system that approaches to produce various decision alternatives to assist certain parties in handling problems using data and various decision-making models. Decision-making model is adjusted to the number of variables, weighting, matrix multiplication and decision making flow. A decision making system only provides an alternative decision and then submitted to the user as the final decision maker [3].

The model that describes the decision-making process consists of four phases, namely [3]:

- Search (Intelligence)

This stage is the stage of defining the problem and the identification of the required information relating to the problems faced and the decisions to be taken. - Design (Design)

This stage is a process to represent the model of the system to be built based on the assumptions that have been set. In this stage, a model of the problem is created, tested and validated.

- Choice (Choice)

* Corresponding author: ilkom.ramadiani@gmail.com 
This stage is a process of testing and selecting the best decision based on certain criteria that have been determined and lead to the goal to be achieved. - Implementation (Implementation)

This stage is the stage of implementation of the decisions that have been taken. At this stage it is necessary to prepare a series of planned actions so that the results of the decisions can be monitored and adjusted as necessary.

\subsection{Simple Additive Weighting}

It is a weighted sum method. The basic concept of the SAW method is to find the weighted sum of performance ratings on each alternative on all criteria [4]. The SAW method requires the process of normalizing the decision matrix $(X)$ to a scale comparable to all existing alternative ratings. The completion step in using it is [4] [5] [6]:

1. Determine the alternative, Ai.

2. Determining the criteria that will be used as a reference in decision making, namely $\mathrm{Cj}$.

3. Provide an alternative match rating on each criterion.

4. Determine the weight of preference or importance level (W) of each criterion.

$W=\left[\begin{array}{lllll}\mathrm{W}_{1} & \mathrm{~W}_{2} & \mathrm{~W}_{3} & \ldots & \mathrm{W}_{\mathrm{j}}\end{array}\right]$

5. Create a match rating table of each alternative on each criteria.

6. Create a decision matrix formed from the match rating table of each alternative on each criterion. The value of $x$ each alternative $(\mathrm{Ai})$ on each criterion $(\mathrm{Cj})$ has been determined.

$$
X=\left[\begin{array}{cccc}
x_{11} & x_{12} & \cdots & x_{1 j} \\
\vdots & & \vdots \\
x_{i 1} & x_{i 2} & \cdots & x_{i j}
\end{array}\right]
$$

where $\mathrm{i}=1,2, \ldots \mathrm{m}$ and $\mathrm{j}=1,2, \ldots \mathrm{n}$.

7. Perform normalize the decision $X$ matrix by calculating the normalized performance $\mathrm{x}$ rating value $\left(r_{i j}\right)$ of the alternative $A_{i}$ on the criterion $\mathrm{C}_{\mathrm{j}}$.

$$
r_{i j}= \begin{cases}\frac{x_{i j}}{\operatorname{Max}_{i}\left(x_{i},\right.} & \text { If } \mathrm{j} \text { is a benefit criterion } \\ \frac{\operatorname{Min}_{i}\left(x_{i j}\right)}{x_{i j}} & \text { If } \mathrm{j} \text { is a cost criterion }\end{cases}
$$

Information :

a. It says the profit criteria if the $x_{i j}$ value provides benefits to the decision maker, otherwise the cost criterion if $x_{i j}$ raises costs for the decision maker.

b. If it is a profit criterion, the value $x_{i j}$ is divided by the value of $\operatorname{Max}_{i}\left(x_{i j}\right)$ of each column, while for the cost criterion, the value $\operatorname{Min}_{i}\left(x_{i j}\right)$ of each column is divided by the value $x_{i j}$.

8. The result of the normalized performance rating value $\left(r_{i j}\right)$ forms a normalized matrix $(\mathrm{R})$.

$$
R=\left[\begin{array}{cccc}
r_{11} & r_{12} & \cdots & r_{1 j} \\
\vdots & & \vdots \\
r_{i 1} & r_{i 2} & \cdots & r_{i j}
\end{array}\right]
$$

9. The end result of the preference value $\left(\mathrm{V}_{\mathrm{i}}\right)$ is derived from the sum of the matrix elements of the normalized matrix row (R) with the corresponding weight of preference (W) of the matrix column element (W).

$$
V_{i}=\sum_{i=1}^{n} \mathrm{~W}_{\mathrm{j}} \mathrm{r}_{\mathrm{ij}}
$$

Greater Vi calculation results indicate that the alternative $\mathrm{Ai}$ is the best alternative.

\subsection{Rabbit Disease}

At first the rabbits are wild animals that live in Africa to mainland Europe. After humans immigrated to various parts of America, Australia, and Asia. In Indonesia, especially in Java, rabbits were brought by the Dutch as ornamental livestock in 1835 [1] [2]. Like other pets the rabbit is susceptible to various diseases, such as:

\subsubsection{Diarrhea}

This disease attacks the digestive tract, and is the most common cause of death in rabbits on farms. The victims are rabbit children who are still nursing. Children of rabbits who recover from this disease subsequent growth is less good, uneconomical if maintained.

\subsubsection{Bloat (Bloated)}

The disease is known by the name of bloating, diarrhea, and bloat. The cause of bloating can be due to humid air, wet, or exposed to the night wind directly, and bad weather. Bloating can also be caused by food, because the ratio of crude fiber, protein, and fat is not appropriate.

\subsubsection{Young Doe Syndrome (Swollen Milk Glands)}

This disease occurs in female rabbits in the first and second birth cohorts. The cause is septicemia due to mastitis resulting in swelling of the milk glands. Staphyloccus aureus germs enter the mammary glands through injuries to the nodes or nipples due to mastitis, heat body temperature, lack of appetite. The nipple is swollen and hard so the mother does not want to breastfeed her child.

\subsubsection{Constipation}

Constipation shows symptoms cannot defecate. Piss very little. Rabbit behavior is very restless. The cause of dry ration is less balanced with sufficient drinking water needs. Raw fiber intakes in dry rations with forage feeds 
are less precise. Rabbits are less mobile because of narrow cages.

\subsubsection{Cold}

Colds cause people to sneeze. Symptoms nose issued lenders clear or cloudy color. The forelegs are always trying to scratch their noses. Feet and body hair come wet. The eyes are puffy, wet, watery. Causes of disease due to bacteria or viruses. The nature of the disease is highly contagious, invading the mucous membranes of the nasal passages. Infection can spread to the throat and lungs causing shortness of breath.

\subsubsection{Scabies}

Scabies cause itching. Parts of the body are attacked first of the head, then spread to the eyes, nose, legs, and then the whole body. The cause of mites Sarcoptes sacbiei so the disease is called scabesiosis scabies. Skin damage causes injury and itching. As a result of skin infections. Reddish skin, hair loss, accompanied by very tortious itching.

\subsubsection{Favus (Infection of the skin)}

Favus is an infection of the scalp caused by a fungus. Attacks on the scalp lead to flat round scales, red, and hard. The scalp looks chapped, and the fur fall off.

\section{Result and Discussion}

\subsection{Data Analysis}

After conducted a collection of research data on diseases that attack the rabbits and their symptoms. The diseases diagnosed in the system can be seen in Table 1.

Table 1. Various Kinds of Rabbit Disease.

\begin{tabular}{|c|l|}
\hline Alternative & Type of Rabbit Disease \\
\hline A1 & Diarrhea \\
\hline A2 & Bloat \\
\hline A3 & $\begin{array}{l}\text { Young Doe Syndrome } \\
\text { (gland inflammation) }\end{array}$ \\
\hline A4 & Constipation \\
\hline A5 & Cold \\
\hline A6 & Scabies (Scabiosis) \\
\hline A7 & Favus (Skin Infections) \\
\hline
\end{tabular}

We can see the determine of disease symptoms in rabbits as in Table 2.
Table 2. Criteria for Rabbit Disease Symptoms

\begin{tabular}{|c|l|}
\hline Crite ria & Symptoms of Rabbit Disease \\
\hline C1 & Appetite \\
\hline C2 & Body temperature \\
\hline C 3 & Sluggish symptoms \\
\hline C4 & Glazed eyes \\
\hline C5 & Diarrhea \\
\hline C6 & Skin scaly / ulcer \\
\hline C7 & Gas formation in the abdomen \\
\hline C 8 & Nipple hard and hot \\
\hline C8 & Shortness of breath \\
\hline C10 & Aqueous nose \\
\hline C11 & Defects \\
\hline C12 & Feathers around the anus \\
\hline
\end{tabular}

Then determined the relation or relationship of each criterion on each alternative, according to Table 3. Where $\mathrm{R}=$ Low, $\mathrm{N}=$ Normal, and $\mathrm{T}=$ Height.

Table 3. Alternative Relations with Criteria

\begin{tabular}{|c|c|c|c|c|c|c|c|}
\hline \multirow{2}{*}{$\begin{array}{c}\text { Symptoms } \\
\text { Code }\end{array}$} & \multicolumn{7}{|c|}{ Disease Code } \\
\hline & A1 & A2 & A3 & A4 & A5 & A6 & A7 \\
\hline $\mathrm{C} 1$ & $\mathrm{R}$ & $\mathrm{R}$ & $\mathrm{T}$ & $\mathrm{R}$ & $\mathrm{R}$ & $\mathrm{R}$ & $\mathrm{R}$ \\
\hline $\mathrm{C} 2$ & $\mathrm{~T}$ & $\mathrm{~T}$ & $\mathrm{~T}$ & $\mathrm{~N}$ & $\mathrm{~N}$ & $\mathrm{~N}$ & $\mathrm{~N}$ \\
\hline $\mathrm{C} 3$ & $\mathrm{~T}$ & $\mathrm{~T}$ & $\mathrm{~T}$ & $\mathrm{~T}$ & $\mathrm{~T}$ & $\mathrm{~T}$ & $\mathrm{~T}$ \\
\hline $\mathrm{C} 4$ & $\mathrm{~T}$ & $\mathrm{~T}$ & $\mathrm{~T}$ & $\mathrm{~T}$ & $\mathrm{~T}$ & $\mathrm{~T}$ & $\mathrm{~T}$ \\
\hline $\mathrm{C} 5$ & $\mathrm{~T}$ & $\mathrm{~T}$ & $\mathrm{~N}$ & $\mathrm{~N}$ & $\mathrm{~N}$ & $\mathrm{~N}$ & $\mathrm{~N}$ \\
\hline C6 & $\mathrm{N}$ & $\mathrm{N}$ & $\mathrm{N}$ & $\mathrm{N}$ & $\mathrm{N}$ & $\mathrm{T}$ & $\mathrm{T}$ \\
\hline $\mathrm{C} 7$ & $\mathrm{~N}$ & $\mathrm{~T}$ & $\mathrm{~N}$ & $\mathrm{~N}$ & $\mathrm{~N}$ & $\mathrm{~N}$ & $\mathrm{~N}$ \\
\hline $\mathrm{C} 8$ & $\mathrm{~N}$ & $\mathrm{~N}$ & $\mathrm{~T}$ & $\mathrm{~N}$ & $\mathrm{~N}$ & $\mathrm{~N}$ & $\mathrm{~N}$ \\
\hline C9 & $\mathrm{N}$ & $\mathrm{N}$ & $\mathrm{N}$ & $\mathrm{N}$ & $\mathrm{T}$ & $\mathrm{N}$ & $\mathrm{N}$ \\
\hline $\mathrm{C} 10$ & $\mathrm{~N}$ & $\mathrm{~N}$ & $\mathrm{~N}$ & $\mathrm{~N}$ & $\mathrm{~T}$ & $\mathrm{~N}$ & $\mathrm{~N}$ \\
\hline $\mathrm{C} 11$ & $\mathrm{~T}$ & $\mathrm{~T}$ & $\mathrm{~N}$ & $\mathrm{R}$ & $\mathrm{N}$ & $\mathrm{N}$ & $\mathrm{N}$ \\
\hline $\mathrm{C} 12$ & $\mathrm{~T}$ & $\mathrm{R}$ & $\mathrm{N}$ & $\mathrm{N}$ & $\mathrm{N}$ & $\mathrm{N}$ & $\mathrm{N}$ \\
\hline
\end{tabular}

\subsection{System Design}

First of all system design is a systematic plan in the process of system development after enough data to support the development activity of rabbit disease diagnosis system. In designing this system the author uses two diagrams Unified Modeling Language (UML) is a use case diagram and activity diagram. 


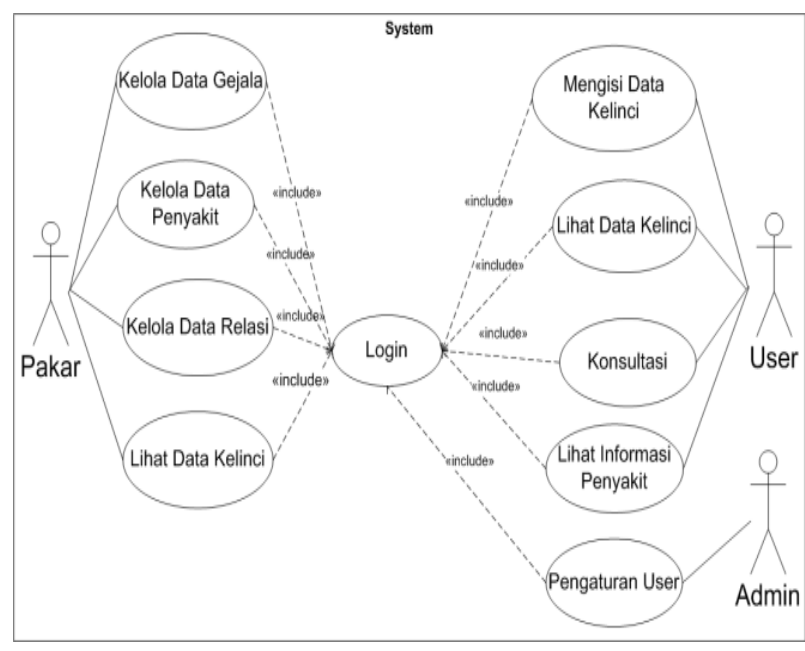

Fig. 1. Use case Diagram System

Figure 1 describes the activities performed by experts, users and admin on the system. Experts performed on this system started by logging into an expert account, after the expert successfully logged in, the expert can manage symptoms data, manage disease data, manage relation data between symptoms with illness, and can see rabbit data.

Activities performed by the user on this system start with login into user account, after user successfully login into account, user can fill rabbit data, see rabbit data, consultation, and see disease information. Activities performed by the admin also begins by logging into the admin account, after admin successfully logged in, the admin can manage the user according to its role.

\subsection{System Implementation}

This stage is important how the stages of the plan, stages of analysis and design stages can be applied to the program so that it can be used in accordance with the purpose of the researcher is making a decision support system to diagnose rabbit disease using Simple Additive Weighting (SAW) method.

\subsubsection{Start Page}

The start page is the initial view from when the user opens the app and the login page. The page for the user enter the system according to his / her interests

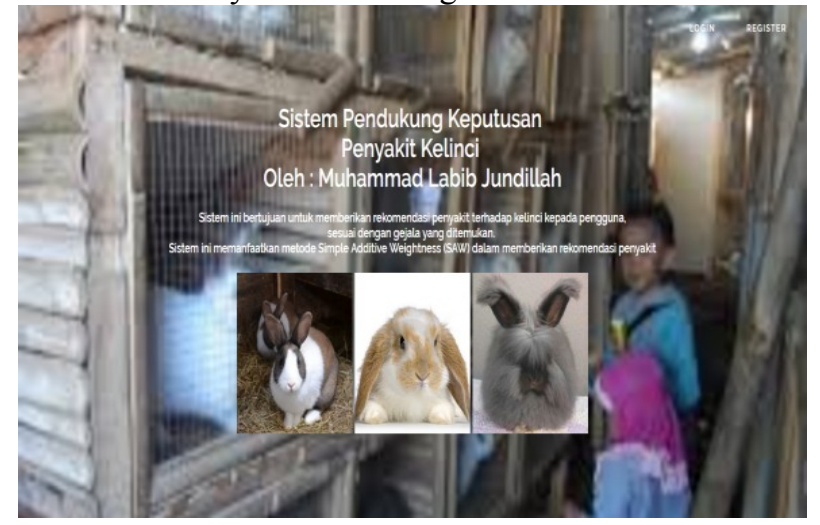

Fig. 2. Start Page

\subsubsection{User Settings Menu}

This menu is only open specifically for operator, where operator can specify user types based on user names that exist within the system.

\subsubsection{Alternative Menu}

This menu is specifically intended for experts in managing alternative data and their relation to criteria.

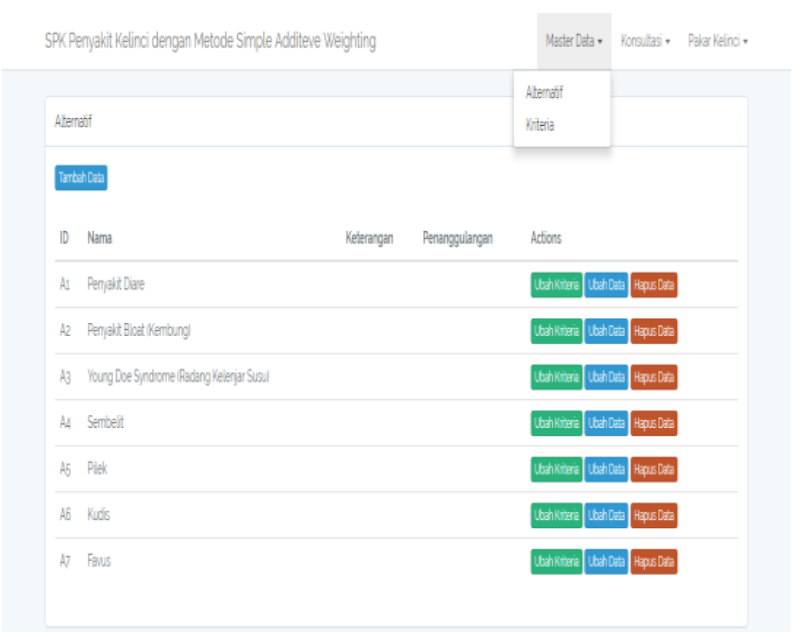

Fig. 3. Alternative Menu

\subsubsection{Criteria Menu}

This criteria menu is also specifically intended for experts to change the criteria data, add criteria data, delete criteria data and determine the weight value of each criterion.

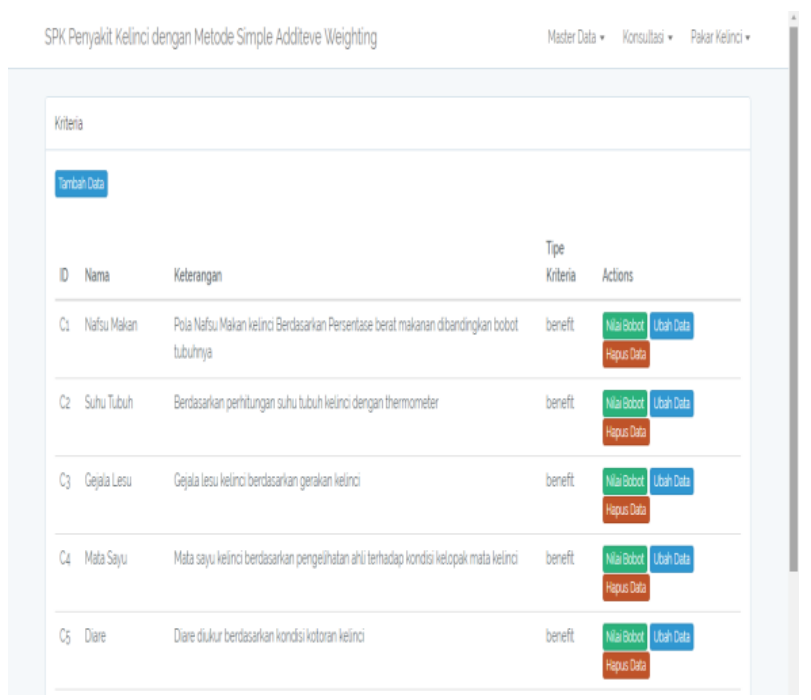

Fig. 4. Criteria Menu

\subsubsection{Rabbit Data Menu}

The rabbit data menu is the menu where the user enters the rabbit data to be diagnosed. 


\subsubsection{Rabbit Data Consultation Form}

This form contains symptom data that must be filled by user based on rabbit circumstance, which will become the reference in generating the diagnosis. After all the symptom data have been filled to full, then pressed consultation button.

\subsubsection{Decision Making Results}

Results of decision-making show the results of the order of calculation using SAW method based on symptoms or criteria that have been entered by the user. Information on the cause and handling it by clicking for details.

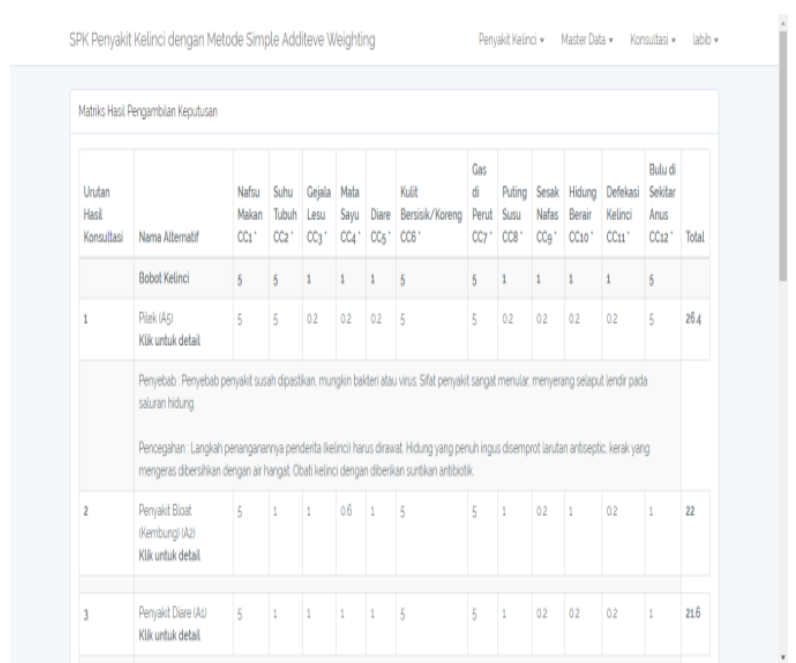

Fig. 5. Results of Decision Making

\subsection{System Testing}

System testing is done to compare between the calculation of the system with manual calculation is appropriate. This manual calculation is performed by the user by inputting the values on the symptoms of the disease. The values are selected and entered by the user according to Table 4 and Table 5 .

Table 4. Parameter Value Testing Criteria

\begin{tabular}{|c|l|c|}
\hline $\begin{array}{c}\text { Symptoms } \\
\text { Code }\end{array}$ & \multicolumn{1}{|c|}{ Symptoms } & $\begin{array}{c}\text { Value } \\
\text { Weight } \\
(\boldsymbol{W})\end{array}$ \\
\hline $\mathrm{C} 1$ & $<10 \%$ body weight (Low) & 5 \\
\hline $\mathrm{C} 2$ & $38,5-40,1^{0}$ C (Normal) & 1 \\
\hline C3 & $\begin{array}{l}\text { Rabbits rarely move } \\
\text { (Height) }\end{array}$ & 5 \\
\hline C4 & His eyes look glazed (High) & 5 \\
\hline C5 & $\begin{array}{l}\text { Feces solid and fluid } \\
\text { defecation (Normal) }\end{array}$ & 1 \\
\hline C6 & $\begin{array}{l}\text { Skin looks healthy and clean } \\
\text { (Normal) }\end{array}$ & 1 \\
\hline C7 & $\begin{array}{l}\text { Abdomen looks healthy } \\
\text { (Normal) }\end{array}$ & 1 \\
\hline C8 & Healthy nipple (Normal) & 1 \\
\hline
\end{tabular}

\begin{tabular}{|c|l|c|}
\hline C9 & $\begin{array}{l}\text { Rabbit looks difficulty } \\
\text { breathing (High) }\end{array}$ & 5 \\
\hline C10 & $\begin{array}{l}\text { There is liquid around the } \\
\text { nose (Height) }\end{array}$ & 5 \\
\hline C11 & $\begin{array}{l}\text { Dispose of water smoothly } \\
\text { (Normal) }\end{array}$ & 1 \\
\hline C12 & Net (Norm) 1 & 1 \\
\hline
\end{tabular}

Table 5. Alternative Value

\begin{tabular}{|l|c|c|c|c|c|c|c|c|c|c|c|c|}
\hline & \multicolumn{10}{|c|}{ Criteria } \\
\cline { 2 - 14 } & C1 & C2 & C3 & C4 & C5 & C6 & C7 & C8 & C9 & C10 & C11 & C12 \\
\hline A1 & 5 & 5 & 5 & 5 & 5 & 1 & 1 & 1 & 1 & 1 & 5 & 5 \\
\hline A2 & 5 & 5 & 5 & 5 & 5 & 1 & 5 & 1 & 1 & 1 & 5 & 5 \\
\hline A3 & 1 & 5 & 5 & 5 & 1 & 1 & 1 & 5 & 1 & 1 & 1 & 1 \\
\hline A4 & 5 & 1 & 5 & 5 & 1 & 1 & 1 & 1 & 1 & 1 & 3 & 1 \\
\hline A5 & 5 & 1 & 5 & 5 & 1 & 1 & 1 & 1 & 5 & 5 & 1 & 1 \\
\hline A6 & 5 & 1 & 5 & 5 & 1 & 5 & 1 & 1 & 1 & 1 & 1 & 1 \\
\hline A7 & 5 & 1 & 5 & 5 & 1 & 5 & 1 & 1 & 1 & 1 & 1 & 1 \\
\hline
\end{tabular}

Then form an $\mathrm{X}$ matrix corresponding to equation (2).

$$
X=\left[\begin{array}{llllllllllll}
5 & 5 & 5 & 5 & 5 & 1 & 1 & 1 & 1 & 1 & 5 & 5 \\
5 & 5 & 5 & 5 & 5 & 1 & 5 & 1 & 1 & 1 & 5 & 5 \\
1 & 5 & 5 & 5 & 1 & 1 & 1 & 5 & 1 & 1 & 1 & 1 \\
5 & 1 & 5 & 5 & 1 & 1 & 1 & 1 & 1 & 1 & 3 & 1 \\
5 & 1 & 5 & 5 & 1 & 1 & 1 & 1 & 5 & 5 & 1 & 1 \\
5 & 1 & 5 & 5 & 1 & 5 & 1 & 1 & 1 & 1 & 1 & 1 \\
5 & 1 & 5 & 5 & 1 & 5 & 1 & 1 & 1 & 1 & 1 & 1
\end{array}\right]
$$

Furthermore, normalize the decision matrix $\mathrm{X}$ with equation (3). So we get the value of matrix normalized $R$ in Table 6.

Table 6. Normalized R.

\begin{tabular}{|c|c|}
\hline$r_{11}=\frac{5}{\operatorname{Max}(5 ; 5 ; 1 ; 5 ; 5 ; 5 ; 5)}=1$ & $r_{12}=\frac{5}{\operatorname{Max}(5 ; 5 ; 5 ; 1 ; 1 ; 1 ; 1)}=1$ \\
\hline$r_{13}=\frac{5}{\operatorname{Max}(5 ; 5 ; 5 ; 5 ; 5 ; 5 ; 5)}=1$ & $\mathrm{r}_{14}=\frac{5}{\operatorname{Max}(5 ; 5 ; 5 ; 5 ; 5 ; 5 ; 5)}=1$ \\
\hline $\mathrm{r}_{15}=\frac{5}{\operatorname{Max}(5 ; 5 ; 1 ; 1 ; 1 ; 1 ; 1)}=1$ & $r_{16}=\frac{1}{\operatorname{Max}(1 ; 1 ; 1 ; 1 ; 1 ; 5 ; 5)}=0.2$ \\
\hline $\mathrm{r}_{17}=\frac{1}{\operatorname{Max}(1 ; 5 ; 1 ; 1 ; 1 ; 1 ; 1)}=0.2$ & $r_{18}=\frac{1}{\operatorname{Max}(1 ; 1 ; 5 ; 1 ; 1 ; 1 ; 1)}=0.2$ \\
\hline$r_{19}=\frac{1}{\operatorname{Max}(1 ; 1 ; 1 ; 1 ; 5 ; 1 ; 1)}=0.2$ & $r_{110}=\frac{1}{\operatorname{Max}(1 ; 1 ; 1 ; 1 ; 5 ; 1 ; 1)}=0.2$ \\
\hline$r_{111}=\frac{5}{\operatorname{Max}(5 ; 5 ; 1 ; 3 ; 1 ; 1 ; 1)}=1$ & $r_{112}=\frac{5}{\operatorname{Max}(5 ; 3 ; 1 ; 1 ; 1 ; 1 ; 1)}=1$ \\
\hline$r_{21}=\frac{5}{\operatorname{Max}(5 ; 5 ; 1 ; 5 ; 5 ; 5 ; 5)}=1$ & $r_{22}=\frac{5}{\operatorname{Max}(5 ; 5 ; 5 ; 1 ; 1 ; 1 ; 1)}=1$ \\
\hline$r_{23}=\frac{5}{\operatorname{Max}(5 ; 5 ; 5 ; 5 ; 5 ; 5 ; 5)}=1$ & $r_{24}=\frac{5}{\operatorname{Max}(5 ; 5 ; 5 ; 5 ; 5 ; 5 ; 5)}=1$ \\
\hline$r_{25}=\frac{5}{\operatorname{Max}(5 ; 5 ; 1 ; 1 ; 1 ; 1 ; 1)}=1$ & $r_{26}=\frac{1}{\operatorname{Max}(1 ; 1 ; 1 ; 1 ; 1 ; 5 ; 5)}=0.2$ \\
\hline $\mathrm{r}_{27}=\frac{5}{\operatorname{Max}(1 ; 5 ; 1 ; 1 ; 1 ; 1 ; 1)}=1$ & $r_{28}=\frac{1}{\operatorname{Max}(1 ; 1 ; 5 ; 1 ; 1 ; 1 ; 1)}=0.2$ \\
\hline$r_{29}=\frac{1}{\operatorname{Max}(1 ; 1 ; 1 ; 1 ; 5 ; 1 ; 1)}=0.2$ & $r_{210}=\frac{1}{\operatorname{Max}(1 ; 1 ; 1 ; 1 ; 5 ; 1 ; 1)}=0.2$ \\
\hline$r_{211}=\frac{5}{\operatorname{Max}(5 ; 5 ; 1 ; 3 ; 1 ; 1 ; 1)}=1$ & $r_{212}=\frac{3}{\operatorname{Max}(5 ; 3 ; 1 ; 1 ; 1 ; 1 ; 1)}=0.6$ \\
\hline$r_{31}=\frac{1}{\operatorname{Max}(5 ; 5 ; 1 ; 5 ; 5 ; 5 ; 5)}=0.2$ & $r_{32}=\frac{5}{\operatorname{Max}(5 ; 5 ; 5 ; 1 ; 1 ; 1 ; 1)}$ \\
\hline$r_{33}=\frac{5}{\operatorname{Max}(5 ; 5 ; 5 ; 5 ; 5 ; 5 ; 5}$ & $=\frac{5}{\operatorname{Max}(5 ; 5 ; 5 ; 5 ; 5 ; 5 ; 5)}=1$ \\
\hline
\end{tabular}




\begin{tabular}{|c|c|}
\hline $\mathrm{r}_{35}=\frac{1}{\operatorname{Max}(5 ; 5 ; 1 ; 1 ; 1 ; 1 ; 1)}=0.2$ & $\mathrm{r}_{36}=\frac{1}{\operatorname{Max}(1 ; 1 ; 1 ; 1 ; 1 ; 5 ; 5)}=0.2$ \\
\hline $\mathrm{r}_{37}=\frac{1}{\operatorname{Max}(1 ; 5 ; 1 ; 1 ; 1 ; 1 ; 1)}=0.2$ & $\mathrm{r}_{38}=\frac{5}{\operatorname{Max}(1 ; 1 ; 5 ; 1 ; 1 ; 1 ; 1)}=1$ \\
\hline$r_{39}=\frac{1}{\operatorname{Max}(1 ; 1 ; 1 ; 1 ; 5 ; 1 ; 1)}=0.2$ & $\mathrm{r}_{310}=\frac{1}{\operatorname{Max}(1 ; 1 ; 1 ; 1 ; 5 ; 1 ; 1)}=0.2$ \\
\hline$r_{311}=\frac{1}{\operatorname{Max}(5 ; 5 ; 1 ; 3 ; 1 ; 1 ; 1)}=0.2$ & $\mathrm{r}_{312}=\frac{1}{\operatorname{Max}(5 ; 3 ; 1 ; 1 ; 1 ; 1 ; 1)}=0.2$ \\
\hline$r_{41}=\frac{5}{\operatorname{Max}(5 ; 5 ; 1 ; 5 ; 5 ; 5 ; 5)}=1$ & $\mathrm{r}_{42}=\frac{1}{\operatorname{Max}(5 ; 5 ; 5 ; 1 ; 1 ; 1 ; 1)}=0.2$ \\
\hline$r_{43}=\frac{5}{\operatorname{Max}(5 ; 5 ; 5 ; 5 ; 5 ; 5 ; 5)}=1$ & $\mathrm{r}_{44}=\frac{5}{\operatorname{Max}(5 ; 5 ; 5 ; 5 ; 5 ; 5 ; 5)}=1$ \\
\hline $\mathrm{r}_{45}=\frac{3}{\operatorname{Max}(5 ; 5 ; 1 ; 1 ; 1 ; 1 ; 1)}=0.6$ & $\mathrm{r}_{46}=\frac{1}{\operatorname{Max}(1 ; 1 ; 1 ; 1 ; 1 ; 5 ; 5)}=0.2$ \\
\hline $\mathrm{r}_{47}=\frac{1}{\operatorname{Max}(1 ; 5 ; 1 ; 1 ; 1 ; 1 ; 1)}=0.2$ & $\mathrm{r}_{48}=\frac{1}{\operatorname{Max}(1 ; 1 ; 5 ; 1 ; 1 ; 1 ; 1)}=0.2$ \\
\hline$r_{49}=\frac{1}{\operatorname{Max}(1 ; 1 ; 1 ; 1 ; 5 ; 1 ; 1)}=0.2$ & $\mathrm{r}_{410}=\frac{1}{\operatorname{Max}(1 ; 1 ; 1 ; 1 ; 5 ; 1 ; 1)}=0.2$ \\
\hline $\mathrm{r}_{411}=\frac{3}{\operatorname{Max}(5 ; 5 ; 1 ; 3 ; 1 ; 1 ; 1)}=0.6$ & $\mathrm{r}_{412}=\frac{1}{\operatorname{Max}(5 ; 3 ; 1 ; 5 ; 1 ; 1 ; 1)}=0.2$ \\
\hline $\mathrm{r}_{51}=\frac{5}{\operatorname{Max}(5 ; 5 ; 1 ; 5 ; 5 ; 5 ; 5)}=1$ & $\mathrm{r}_{52}=\frac{1}{\operatorname{Max}(5 ; 5 ; 5 ; 1 ; 1 ; 1 ; 1)}=0.2$ \\
\hline$r_{53}=\frac{5}{\operatorname{Max}(5 ; 5 ; 5 ; 5 ; 5 ; 5 ; 5)}=1$ & $r_{54}=\frac{5}{\operatorname{Max}(5 ; 5 ; 5 ; 5 ; 5 ; 5 ; 5)}=1$ \\
\hline$r_{55}=\frac{1}{\operatorname{Max}(5 ; 5 ; 1 ; 1 ; 1 ; 1 ; 1)}=0.2$ & $\mathrm{r}_{56}=\frac{1}{\operatorname{Max}(1 ; 1 ; 1 ; 1 ; 1 ; 5 ; 5)}=0.2$ \\
\hline $\mathrm{r}_{57}=\frac{1}{\operatorname{Max}(1 ; 5 ; 1 ; 1 ; 1 ; 1 ; 1)}=0.2$ & $\mathrm{r}_{58}=\frac{1}{\operatorname{Max}(1 ; 1 ; 5 ; 1 ; 1 ; 1 ; 1)}=0.2$ \\
\hline$r_{59}=\frac{5}{\operatorname{Max}(1: 1: 1 ; 1 ; 5 ; 1: 1)}=1$ & $\mathrm{r}_{510}=\frac{5}{\operatorname{Max}(1: 1: 1: 1: 5 ; 1: 1)}=1$ \\
\hline $\mathrm{r}_{511}=\frac{1}{\operatorname{Max}(5 ; 5 ; 1 ; 3 ; 1 ; 1 ; 1)}=0.2$ & $\mathrm{r}_{512}=\frac{1}{\operatorname{Max}(5 ; 3 ; 1 ; 1 ; 1 ; 1 ; 1)}=0.2$ \\
\hline $\mathrm{r}_{61}=\frac{5}{\operatorname{Max}(5 ; 5 ; 1 ; 5 ; 5 ; 5 ; 5)}=1$ & $\mathrm{r}_{62}=\frac{1}{\operatorname{Max}(5 ; 5 ; 5 ; 1 ; 1 ; 1 ; 1)}=0.2$ \\
\hline$r_{63}=\frac{5}{\operatorname{Max}(5 ; 5 ; 5 ; 5 ; 5 ; 5 ; 5)}=1$ & $\frac{5}{5 ; 5 ; 5 ; 5 ; 5 ; 5 ; 5)}=1$ \\
\hline$r_{65}=\frac{1}{\operatorname{Max}(5 ; 5 ; 1 ; 1 ; 1 ; 1 ; 1)}=0.2$ & $\mathrm{r}_{66}=\frac{5}{\operatorname{Max}(1 ; 1 ; 1 ; 1 ; 1 ; 5 ; 5)}=1$ \\
\hline $\mathrm{r}_{67}=\frac{1}{\operatorname{Max}(1 ; 5 ; 1 ; 1 ; 1 ; 1 ; 1)}=0.2$ & $\mathrm{r}_{68}=\frac{1}{\operatorname{Max}(1 ; 1 ; 5 ; 1 ; 1 ; 1 ; 1)}=0.2$ \\
\hline$r_{68}=\frac{1}{\operatorname{Max}(1 ; 1 ; 5 ; 1 ; 1 ; 1 ; 1)}=0.2$ & $\mathrm{r}_{610}=\frac{1}{\operatorname{Max}(1 ; 1 ; 1 ; 1 ; 5 ; 1 ; 1)}=0.2$ \\
\hline $\mathrm{r}_{611}=\frac{1}{\operatorname{Max}(5 ; 5 ; 1 ; 3 ; 1 ; 1 ; 1)}=0.2$ & $\mathrm{r}_{612}=\frac{1}{\operatorname{Max}(5 ; 3 ; 1 ; 1 ; 1 ; 1 ; 1)}=0.2$ \\
\hline$r_{71}=\frac{5}{\operatorname{Max}(5 ; 5 ; 1 ; 5 ; 5 ; 5 ; 5)}=1$ & $\mathrm{r}_{72}=\frac{1}{a x(5 ; 5 ; 5 ; 1 ; 1 ; 1 ; 1)}=0.2$ \\
\hline$r_{73}=\frac{5}{\operatorname{Max}(5 ; 5 ; 5 ; 5 ; 5 ; 5 ; 5)}=1$ & $\mathrm{r}_{74}=\frac{5}{\operatorname{Max}(5 ; 5 ; 5 ; 5 ; 5 ; 5 ; 5)}=1$ \\
\hline $\mathrm{r}_{75}=\frac{1}{\operatorname{Max}(5 ; 5 ; 1 ; 1 ; 1 ; 1 ; 1)}=0.2$ & $\mathrm{r}_{76}=\frac{5}{\operatorname{Max}(1 ; 1 ; 1 ; 1 ; 1 ; 5 ; 5)}=1$ \\
\hline $\mathrm{r}_{77}=\frac{1}{\operatorname{Max}(1 ; 5 ; 1 ; 1 ; 1 ; 1 ; 1)}=0.2$ & $\mathrm{r}_{78}=\frac{1}{\operatorname{Max}(1 ; 1 ; 5 ; 1 ; 1 ; 1 ; 1)}=0.2$ \\
\hline $\mathrm{r}_{79}=\frac{1}{\operatorname{Max}(1 ; 1 ; 1 ; 1 ; 5 ; 1 ; 1)}=0.2$ & $\mathrm{r}_{710}=\frac{1}{\operatorname{Max}(1 ; 1 ; 1 ; 1 ; 5 ; 1 ; 1)}=0.2$ \\
\hline $\mathrm{r}_{711}=\frac{1}{\operatorname{Max}(5 ; 5 ; 1 ; 3 ; 1 ; 1 ; 1)}=0.2$ & $\mathrm{r}_{712}=\frac{1}{\operatorname{Max}(5 ; 3 ; 1 ; 1 ; 1 ; 1 ; 1)}$ \\
\hline
\end{tabular}

$\mathrm{R}=\left[\begin{array}{cccccccccccc}1 & 1 & 1 & 1 & 1 & 0.2 & 0.2 & 0.2 & 0.2 & 0.2 & 1 & 1 \\ 1 & 1 & 1 & 1 & 1 & 0.2 & 1 & 0.2 & 0.2 & 0.2 & 1 & 0.6 \\ 0.2 & 1 & 1 & 1 & 0.2 & 0.2 & 0.2 & 1 & 0.2 & 0.2 & 0.2 & 0.2 \\ 1 & 0.2 & 1 & 1 & 0.2 & 0.2 & 0.2 & 0.2 & 0.2 & 0.2 & 0.6 & 0.2 \\ 1 & 0.2 & 1 & 1 & 0.2 & 0.2 & 0,2 & 0.2 & 1 & 1 & 0.2 & 0.2 \\ 1 & 0.2 & 1 & 1 & 0.2 & 1 & 0.2 & 0.2 & 0.2 & 0.2 & 0.2 & 0.2 \\ 1 & 0.2 & 1 & 1 & 0.2 & 1 & 0.2 & 0.2 & 0.2 & 0.2 & 0.2 & 0.2\end{array}\right]$

Next is process of calculating preference (V) by using the following equation. The end result of the preference value (Vi) is derived from the sum of the matrix elements of the normalized matrix row (R) with the corresponding weight of preference (W) of the matrix column element (W). V larger value indicates that the alternative V5 is the best alternative, in other words, A5 were the best alternative decision using Simple Additive Weighting method (Table 7).

Table 7. The Preference Value Vi

\begin{tabular}{|c|c|}
\hline No & (Vi) \\
\hline 1 & $\begin{aligned} & =(1 \times 5)+(1 \times 1)+(1 \times 5)+(1 \times 5)+(1 \times 1)+(0.2 \times 1)+ \\
& (0.2 \times 1)+(0.2 \times 1)+(0.2 \times 5)+(0.2 \times 5)+(1 \times 1)+(1 \times 1) \\
& =5+1+5+5+1+0.2+0.2+0.2+1+1+1+1 \\
& =21.6\end{aligned}$ \\
\hline 2 & $\begin{aligned}= & (1 \times 5)+(1 \times 1)+(1 \times 5)+(1 \times 5)+(1 \times 1)+(0.2 \times 1)+ \\
& (1 \times 1)+(0.2 \times 1)+(0.2 \times 5)+(0.2 \times 5)+(1 \times 1)+(0.6 \times 1) \\
= & 5+1+5+5+1+0.2+1+0.2+1+1+1+0.6 \\
= & 22\end{aligned}$ \\
\hline 3 & $\begin{aligned}= & (0.2 \times 5)+(1 \times 1)+(1 \times 5)+(1 \times 5)+(0.2 \times 1)+(0.2 \times 1)+ \\
& (0.2 \times 1)+(1 \times 1)+(0.2 \times 5)+(0.2 \times 5)+(0.2 \times 1)+(0.2 \times 1) \\
= & 1+1+5+5+0.2+0.2+0.2+1+1+1+0.2+0.2 \\
= & 16\end{aligned}$ \\
\hline 4 & $\begin{aligned}= & (1 \times 5)+(0.2 \times 1)+(1 \times 5)+(1 \times 5)+(0.2 \times 1)+(0.2 \times 1)+ \\
& (0.2 \times 1)+(0.2 \times 1)+(0.2 \times 5)+(0.2 \times 5)+(0.6 \times 1)+ \\
& (0.2 \times 1) \\
= & 5+0.2+5+5+0.2+0.2+0.2+0.2+1+1+0.6+0.2 \\
= & 18.8\end{aligned}$ \\
\hline 5 & $\begin{aligned} V_{\text {ᄃ }}= & (1 \times 5)+(0.2 \times 1)+(1 \times 5)+(1 \times 5)+(0.2 \times 1)+(0.2 \times 1)+ \\
& (0.2 \times 1)+(0.2 \times 1)+(1 \times 5)+(1 \times 5)+(0.2 \times 1)+(0.2 \times 1) \\
= & 5+0.2+5+5+0.2+0.2+0.2+0.2+5+5+0.2+0.2 \\
= & \mathbf{2 6 . 4}\end{aligned}$ \\
\hline 6 & $\begin{aligned}= & (1 \times 5)+(0.2 \times 1)+(1 \times 5)+(1 \times 5)+(0.2 \times 1)+(1 \times 1)+ \\
& (0.2 \times 1)+(0.2 \times 1)+(0.2 \times 5)+(0.2 \times 5)+(0.2 \times 1)+ \\
& (0.2 \times 1) \\
= & 5+0.2+5+5+0.2+1+0.2+0.2+1+1+0.2+0.2 \\
= & 19.2\end{aligned}$ \\
\hline 7 & $\begin{array}{l}=(1 \times 5)+(0.2 \times 1)+(1 \times 5)+(1 \times 5)+(0.2 \times 1)+(1 \times 1)+ \\
(0.2 \times 1)+(0.2 \times 1)+(0.2 \times 5)+(0.2 \times 5)+(0.2 \times 1)+(0.2 \times) \\
=5+0.2+5+5+0.2+1+0.2+0.2+1+1+0.2+0.2 \\
=19.2\end{array}$ \\
\hline
\end{tabular}

Determine the final result of the preference value using equation (5). So we get the ordering of the calculation result is:

Cold Disease $V_{5}=\mathbf{2 6 . 4}$

Bloating Disease $V_{3}=22$

Diarrhea Disease $V_{1}=21.6$

Mange Disease $V_{c}=19.2$

Favus disease $V_{7}=19.2$

Constipation Disease $V_{\Delta}=18.4$

The result of the calculation is $V_{5}=26.4$ has the greatest value, so the result of diagnosis is Colds disease. System diagnostic results are: Rabbits have the possibility of having a cold with the largest preference value of 26.4. So the result of calculation system compared with manual calculation accordingly.

How to overcome disease in the system is step handling patients (rabbits) should be treated. The snotnosed nose was sprayed with an antiseptic solution, a hardened crust cleansed with warm water. Treat the rabbit with a given antibiotic injection. 


\section{Conclusions}

From the implementation that has been done, there are some conclusions that can be presented as a result of research. This research has produced a decision support system for the diagnosis of the rabbit disease on the webbased with Simple Additive weighting method (SAW). It can assist the public in providing a diagnosis on the sick rabbit.

The decision support system works based on symptoms that have been selected by the user and processed by the system so as to produce a diagnosis of rabbit disease. Based on the computation calculations performed manually and done with the system then it can be concluded from both the manual calculation and the system, yielding the same value with the same disease.

\section{References}

1. B. Sarwono, Kelinci Potong dan Hias, Jakarta : Agro Media Pustaka (2010).

2. R. Hustamin, Panduan Memelihara Kelinci Hias, Jakarta : Agro Media (2006).

3. E. Turban, Decision Support System and Inteligent Systems. Jilid1. Edisi 7. Yogyakarta: Penerbit Andi (2005).

4. Kusumadewi, Sri, dkk. Fuzzy Multi Attribute Decision Making. Yogyakarta (2006).

5. Nurmalini1, R. Robbi, IJSRST Vol. 3: 541-544, March-April (2017).

6. Risawandi, R. Robbi, IJSRST Vol. 3: 491-494, NovDec (2016). 